\title{
Role of Platelets, Bacterial Vaginosis, Serum Interleukins and TNF In Genital Human Papillomavirus Infection Among Black Female Population in Nigeria
}

\author{
Yibala Ibor Oboma*1, Easter Godwin Nwokah ${ }^{2}$ and Stephen 0 Elesha $^{3}$ \\ ${ }^{1}$ Department of Medical Laboratory science, Faculty of Basic Medical Sciences, College of health Sciences, Niger Delta University
} Wilberforce Island Bayelsa State, Nigeria

2Department of Medical Laboratory Science, Rivers State University, Nkpolu-Oroworukwo, Port Harcourt, Nigeria

3Department of Anatomical Pathology, Faculty of Basic Medical Sciences, College of health Sciences, Niger Delta University Wilberforce Island Bayelsa State, Nigeria

*Corresponding author: Yibala Oboma, Department of Medical Laboratory Science, Faculty of Basic Medical Sciences, College of

Health Sciences, Niger Delta University, Wilberforce Island, Bayelsa State, Nigeria

\section{ARTICLE INFO}

Received: 幽 February 18, 2020

Published: 蔧 February 27, 2020

Citation: Yibala Ibor Oboma, Easter Godwin Nwokah, Stephen O Elesha. Role of Platelets, Bacterial Vaginosis, Serum Interleukins and TNF In Genital Human Papillomavirus Infection Among Black Female Population in Nigeria. Biomed J Sci \& Tech Res 26(1)2020. BJSTR. MS.ID.004296.

Keywords: Platelets; HPV; Interleukins Bayelsa

Abbreviations: TNF: Tumor Necrotic Factor, LCMV: Lymphocytic Choriomeningitis Virus, OD: Optical Density, HRP: Horseradish Peroxidase, BV: Bacterial Vaginosis

\section{ABSTRACT}

The study was aimed at evaluating the relationship between platelets count, bacterial vaginosis and immune response in cervical human Papillomavirus positive women in Bayelsa State. Cervical smears were collected from apparently healthy subjects attending clinics in Bayelsa State. Consensus primers GP5+/6+ and MY09/11 were used to detect HPV DNA in cervical smears and further subjected to multiplex PCR for molecular typing of HPV subtypes. Nugent method was used for scoring of bacterial vaginoses based on gram staining reaction. Interleukins were studied using sandwich ELISA kits. The prevalence of bacterial vaginosis among HPV positive, HPV negative and high-risk HPV was $35.9 \%$ and $18.2 \%$ and $51.7 \%$ respectively. Bacterial vaginosis expressed statistically significant relationship with high risk HPV (OR=9.64, P=0.002, $95 \% \mathrm{CI}=1.08-86.26)$.Interleukin 4 (IL-4), IL-6, IL-8, IL-10, IL-12, IL-17, IL-18, Tumor Necrotic Factor (TNF) and Interferon Gamma (INF- $\gamma$ ) were equally higher in HPV positive participants compared with negative participants and statistically significant. There exists a statistically significantly decrease in platelets count $(227.8 \pm 57)$ of HPV positive participants compared with negative participants $(259.3 \pm 57),(\mathrm{X} 2=6.8, \mathrm{P}=0.01)$ as well as neutrophils count of $45.2 \pm 8.5$ of HPV positive compared with negative participants (50.6 \pm 8.4$),\left(\mathrm{X}^{2}=2.9, \mathrm{P}=0.01\right)$.White blood cell count, monocytes and packed cell volume were equally higher in positive cases compared with negative cases. Bacterial Vaginosis showed a strong relationship with high risk human Papillomavirus, indicating that a healthy vaginal flora will not only protect a woman from the acquisition of sexually transmitted viruses but also high-risk HPV. Interleukins participate in HPV infection and association interferon levels were depleted in HPV infected participants. Thrombocytes and neutrophils are cellular mediators in genital HPV infection. It is recommended therefore that women exposed to high-risk HPV should be screened for bacterial vaginosis, with concomitant estimations of levels of platelets as well as inflammatory cytokines.

\section{Introduction}

Estimated population of 47 million women aged 15 years and above are at risk of developing cervical cancer worldwide. There are reported rising incidence of cervical dysplasiain Nigeria according to the information center on HPV and cancer based on various 
studies done in population in Nigeria [1]. Cell growth, function and differentiation, steering immunological response and inflammatory processes are initiated by certain biological molecules known as cytokines [2]. These cytokines and chemokines are secreted by keratinocytes which are either activated or suppressed by the immune system as they participate in human Papillomavirus infection. Certain cells like the dendritic cells, Langerhans cells, natural killer cells, and natural killer T-helper cells among others are also involved in promoting immune response against HPV infection [3]. A delicate balance exists between pro-inflammatory and anti-inflammatory cytokines and their disturbances as reported in many acute disease conditions like pyrexia, rheumatic disorders and cancers. In histological sections, cervical Papillomatosis is characterized by marked keratinocyte hyperproliferation, dense inflammatory infiltrate consisting of T-helper cells and neutrophils, vascular dilatation and proliferation.

The primary defect in Papillomatosis patients is believed to be abnormal thickening of epidermal cells [4]. Genetic variations in IL-6, IL-8 or IL-10 polymorphisms is associated with the risk of cervical cancer. Also, circulating levels of cytokines IL-2, IFN-a B, IL-2, IL-8, and IL-10 are useful in identifying women at higher risk of developing cervical invasive cancer, LSIL or HSIL, and risk of metastasis. Circulating or tissue levels of IL-6, IL-8 and IL-10 serve as additional markers in the prognosis of patients with advanced stage disease and may help the decision-making processes [2]. Platelets disorders have been reported in certain viral infection like human immunodeficiency virus where surface glycoprotein gp120 causes an increase in megakaryocyte apoptosis in vitro due to increased $\mathrm{TGFb}$ and down regulation of the proliferation, inducing TNF super family member 13(TNFSF13). The envelope protein gp120 also interacts with CD4, which is expressed by immature megakaryocyte expressing CCR5 in infectious state [5]. Zapata, et al. [6] documented that in dengue virus infection, platelet production is impaired by suppression of megakaryopoiesis via infection of hematopoietic progenitor cells or indirectly via altered cytokine levels in the bone marrow due to impaired stroma cell function.

Iannacone, et al. [7] and Pozner, et al. [8] reported that in Arena virus infection by either Lymphocytic Choriomeningitis Virus (LCMV) or Junin virus results in thrombocytopenia and decreased platelet responses in mice. Lutteke, et al. [9] reported that Hantavirus' directly interact with and activate platelets via GPIIb/IIIa'. Infection of megakaryocyte with Hantavirus induces the up regulation of Human Leukocyte Antigen (HLA) class 1 molecules on the megakaryocyte surface leading to cytotoxic T-lymphocytemediated destruction of megakaryocyte. Influenza and other viruses possess enzymes which can modulate platelet functions and promote neuraminidase which causes hydrolyses of the terminal sialic acid residues from host cell receptor thereby decreasing the life span of platelets, by targeting platelets for rapid clearance in the liver and spleen. Metcalfpate, et al. [10] and Singh, et al. [11] documented that human parvovirus do not has the ability to reproduce itself in megakaryocyte, but rather triggers a downward activation in platelet count via platelet activation. Therefore, the need to establish the effect of genital HPV on platelets count, interleukins and bacterial vaginosis among women in Bayelsa State.

\section{Materials and Methods}

\section{Study Population/ Sampling}

Fifty apparently health persons attending two hospitals in Bayelsa State participated in the study. Snowball and convenient sampling were the sampling methods adopted. Cervical-vaginal smears samples collection was done under aseptic technique; cervical smears were collected using Cytobrush and disposable speculum and swab stick respectively. Smears were made and the remaining stored in phosphate buffer used for DNA extraction for HPV detection and identification. Also, $6 \mathrm{mls}$ of venous blood was equally collected from each participant and dispensed into EDTA containers for blood count and $4 \mathrm{mls}$ into plain containers for interleukins estimation.

\section{Interleukins}

The serum circulating interleukins (IL-4, IL-6,IL- 8, IL-10, IL-12, IL-17, IL-18), interferon gamma (INF-) and TNF mean concentration were assayed using reagents from Elabscience(R), a USA-based company and in accordance with the method of Nnodi, et al. [12]. The process required multi-step washing, rinsing and soaking. The ELISA kits use sandwich ELISA principle. The Standards sera and the test samples were added to appropriate micro ELISA wells impregnated with a capture antibody. Then a biotinylated detection antibody specific for the interleukin and avidin Horseradish Peroxidase (HRP)conjugate was successively added and incubated at $37^{\circ} \mathrm{c}$. Color (blue) was developed using substrate reagent to form enzyme-substrate complex. The enzyme-substrate reaction was terminated with a stop solution and appeared yellow in color. The Optical Density (OD) was measured using a spectrophotometer at 450nm using Opsys DYNEX technologies serial NO: PMRA-2976 ELISA micro plate reader. Optical Density (OD) was proportional to the serum interleukin concentration in each well.

The serum interleukin mean concentration was calculated comparing the optical density of the test serum sample with the standard curve. Standard working solution of different concentrations in serial dilution gradients $(1000,500,250,125$, $62.5,31.25,15.63$ and $0 \mathrm{pg}$. / $\mathrm{ml}$ were prepared. Then $100 \mathrm{uL}$ of each concentration was added into the two wells side by side and $100 \mathrm{uL}$ of each serum was added into duplicate wells side by side. The ELISA wells were covered and incubated for $90 \mathrm{~min}$. at $37^{\circ} \mathrm{C}$. Excess liquid on each well was removed without washing and immediately, 100uL of biotinylated detection antibody working solution was added into the wells, covered and gently mixed and incubated for another $1 \mathrm{hr}$. at $37^{\circ} \mathrm{C}$. The wells were decanted and $350 \mathrm{uL}$ of wash 
buffer added to each well, soaked for $2 \mathrm{~min}$, decanted and pat-dried followed by addition of $100 \mathrm{uL}$ of HRP conjugate working solution to each well, covered and incubated for $30 \mathrm{~min}$. at $37^{\circ} \mathrm{C}$. The wells were decanted and washed with $350 \mathrm{uL}$ wash buffer, soaked for 5 min decanted pat dry for 5 times. Substrate reagent (90uL) was added to each well, covered and incubated for $15 \mathrm{~min}$. at $37^{\circ} \mathrm{C}$. with maximum protection from light. Thereafter, $50 \mathrm{uL}$ of the stop solution was added to stop the reaction. The optical density of each well was determined at once with a micro plate reader set to $450 \mathrm{~nm}$.

\section{Blood Count}

Blood count of the participants was assayed using automated hematology analyzer in accordance with the method of Schapkaitz and Levy [13]. The blood count analysis was based on the principle of electrical impedance. The impedance changes as the blood passed through the orifices. The change in impedance is proportional to cell volume, resulting in cell count and volume. The impedance analysis returns blood count in three parts white blood cell differentials (granulocytes, lymphocytes and monocytes) but unable to distinguish between similarly sized granular leucocytes: eosinophil, basophils and neutrophils. The procedure involves passing $2 \mathrm{ml}$ of venous blood collected from each participant into EDTA containers into an orifice attached to the machine. The EDTA blood container was vortexed and passed through a tiny orifice in the automated hematology analyzer and the machine sucked an aliquot of the blood sample in the container and within $30 \mathrm{sec}$ results were displayed on the screen and were printed.

\section{Bacterial Vaginosis}

The methodologies of Nugent, et al. and Mendoza, et al. [14,15] were adopted. The principle of the reaction is based on Gram staining reaction. A score of 0 to 3 large gram-positive rods was considered normal, 4 to 6 rods was classified as abnormal vaginal flora (or intermediate) and 7 to 10 was indicative of bacterial Vaginosis. A sterile swab stick was used to collect the samples from the vagina of the participants to make a thin smear. The smears were air-dried and protected from contaminants and then fixed in absolute ethanol for $15 \mathrm{~min}$. The fixed smears were flooded with crystal violet stain for $1 \mathrm{~min}$ and rapidly washed away with distilled water. They were drained and flooded again with Lugol's iodine for $1 \mathrm{~min}$, decolorized rapidly (for 2 secs) with acetone and washed immediately with clean water and covered with safranin stain for $2 \mathrm{~min}$. The excess stain was washed off with water, allowed to drain and air-dried and examined microscopically first with X40 objective to check staining and then X100 oil immersion objectives to report bacteria rods, yeast cells, pus cells and epithelial cells.

\section{Multiplex PCR Protocol}

Seventeen (17) HPV genotypes (6, 11, 16L 16U, 18, 30 31, 33, $35,39,45,51,52,56,58,59,66)$ were studied using the method of Nistiwaki, et al. [16] in a single tube multiplex PCR. Multiplex polymerase chain reaction is a technique by which different samples of DNA are amplified in one single reaction and used for detection and identification of large number of mutation or organisms depending on their molecular size. This process amplifies DNA in a sample using multiple primers, 2X Master Mix and a temperaturemediated DNA polymerase in a thermal cycler. Optimization of the primers was carriedout to allow the primers work at the same annealing temperature. The PCR mixture included $2 x$ multiplex master mix (Taq polymerase, dNTPs, $\mathrm{MgCl}_{2}$ ) forward and reverse primers at concentration of $0.1 \mu \mathrm{l}$ each and $3.0 \mathrm{ul}$ of the extracted DNA. Nuclease-free water of $6.92 \mu \mathrm{l}$ was used to make up to the PCR mixture of a final volume of $30 \mu$ l. Each PCR was carried out in a DNA thermal cycler (Gene Amp PCR system 9700, Singapore) in the following conditions; initial denaturation step at $95^{\circ} \mathrm{C}$ for $5 \mathrm{~min}, 40$ cycles of denaturation step at $94^{\circ} \mathrm{C}$ for $30 \mathrm{sec}$, annealing at $65^{\circ} \mathrm{C}$ for $60 \mathrm{sec}$ and initial extension at $72^{\circ} \mathrm{C}$ for $90 \mathrm{sec}$ with final extension at $72^{\circ} \mathrm{C}$ for $5 \mathrm{~min}$. The PCR products were analyzed by electrophoresis on a $2 \%$ agarose gel stained with ethidium bromide with band sizes estimated by comparison with 100bp molecular marker (Quickload DNA molecular ladder, NECO England Biolabs Inc.).

\section{Result}

Serum interleukins mean concentration was high in women with cervical HPV and statistically significant, compared with HPV negative women. Interleukin 4 (IL-4), IL-6, IL-8, IL-10, IL-12, IL-17, IL-18 while Tumor Necrotic Factor (TNF)) and interferon gamma (INF-) were equally lower in HPV positive participants compared with negative participants and was statistically significant in either reduction or increases in their mean concentration as seen in (Tables 1 \& 2). Also, bacterial vaginosis expresses statistically significant relationship with high risk HPV $(\mathrm{OR}=9.64, \mathrm{P}=0.002$, $95 \% \mathrm{CI}=1.08-86.26)$ but no statistically insignificant relation with HPV DNA positive women. Furthermore, blood count (Red blood cells, White blood cells count, platelets count, mean cell hemoglobin concentration, hemoglobin, packed cell volume, percentage neutrophils, lymphocytes and monocytes among HPV positive participant and HPV negative participants were studied. There exists a statistically significantly decrease in platelets count (227.8 \pm 57 ) of HPV positive participants compared with negative participants(259.3 \pm 57$),\left(\mathrm{X}^{2}=6.8, \mathrm{P}=0.01\right)$ as well as neutrophils count of $45.2 \pm 8.5$ of HPV positive compared with negative participants $(50.6 \pm 8.4),\left(X^{2}=2.9, P=0.01\right)$. Again, there was no statistical relationship in mean red blood cells ( $4.4 \pm 0.5$ vs. $4.5 \pm 0.5)$ of HPV positive and HPV negative subjects. Mean cell volume ( $84.7 \pm 6.2$ vs. $86.8 \pm 6.6$ ), \% lymphocytes ( $44.4 \pm 7.3$ vs. $45.0 \pm 8.3$ ) in HPV positive compared with negative participants showed no significant association. The white blood cell count, monocytes and packed cell volume were equally higher in positive cases compared with negative cases. 
Table 1: Multiplex Primers Synthesis.

\begin{tabular}{|c|c|c|c|c|c|c|}
\hline S/no & HPV Primer & Forward and Reverse primer sequence & Size (bp) & Length & GC \% & $\operatorname{Tm}^{\circ} \mathrm{C}$ \\
\hline \multirow[t]{2}{*}{1} & pp x6/F & GCTAAAGGTCCTGTTTCGAGGCGGCTA & 263 & 27 & $55.56 / 55.56$ & $69.16 / 69.16$ \\
\hline & PPx6/R & GGCAGCGACCCTTCCACGTACAAT & & 24 & $58.33 / 58.33$ & $67.98 / 67.98$ \\
\hline \multirow[t]{2}{*}{2} & $\mathrm{pp} \times 11 / \mathrm{F}$ & GCGTGTTTTGCAGGAATGCACTGAC & 472 & 25 & $52 / 52$ & $66.22 / 66.22$ \\
\hline & $\mathrm{pp} \times 11 \mathrm{R}$ & TGCGTCTTGTTTGTCCACCTTGTCC & & 25 & $52 / 52$ & $66.22 / 66.22$ \\
\hline \multirow[t]{2}{*}{3} & $\mathrm{pp} \times 16 \mathrm{~L} / \mathrm{F}$ & CGCACAAAACGTGCATCGGCTACC & 217 & 24 & $67.08 / 67.08$ & $58.33 / 58.33$ \\
\hline & $\mathrm{pp} \times 16 \mathrm{~L} / \mathrm{R}$ & TGGGAGGCCTTGTTCCCAATGGA & & 23 & $56.52 / 56.52$ & $66.33 / 66.33$ \\
\hline \multirow[t]{2}{*}{4} & $\mathrm{PPx} 16 \mathrm{U} / \mathrm{F}$ & TCCTGCAGGTACCAATGGGGAAGAGG & 397 & 26 & $57.69 / 57.69$ & $69.32 / 69.32$ \\
\hline & $\mathrm{PP} \times 16 \mathrm{U} / \mathrm{R}$ & TGCCATACCCGCTGTCTTCGCTTT & & 24 & $54.17 / 54.17$ & $66.28 / 66.28$ \\
\hline \multirow[t]{2}{*}{5} & PPx18/F & AACAGTCCATTAGGGGAGCGGCTGGA & 187 & 26 & $57.69 / 67.69$ & $69.32 / 69.32$ \\
\hline & $\mathrm{PP} \times 18 / \mathrm{R}$ & TGCCGCCATGTTCGCATTTG & & 21 & $57.14 / 57.14$ & $64.52 / 64.32$ \\
\hline \multirow[t]{2}{*}{6} & $\mathrm{ppx30/F}$ & ACGTAGACGAAAACGGGCCTCTGCT & 249 & 25 & $60 / 60$ & $69.5 / 69.5$ \\
\hline & $\mathrm{ppx} 30 / \mathrm{R}$ & GGCCTAGCAGGGGATGCGTCCACA & & 24 & $66.67 / 66.67$ & $71.4 / 71.4$ \\
\hline \multirow[t]{2}{*}{7} & Ppx31/F & GCGGTCCAAACGCTCTACAAAACGCACT & 360 & 28 & $53.57 / 53.57$ & $69.01 / 69.01$ \\
\hline & $\mathrm{PPx} 31 / \mathrm{R}$ & GCAGGGGCACCAACATCAACAATTCCA & & 27 & $51.85 / 51.85$ & $67.64 / 67.64$ \\
\hline \multirow[t]{2}{*}{8} & $\mathrm{pp} \times 33 / \mathrm{F}$ & ACACAGAGGCAGCCCGGGCATTGTTT & 139 & 26 & $57.69 / 57.69$ & $69.32 / 69.32$ \\
\hline & $\mathrm{ppx33/R}$ & CACGGGTTTGCAGCACGATCAACA & & 24 & $54.17 / 54.17$ & $66.28 / 66.28$ \\
\hline \multirow[t]{2}{*}{9} & $\mathrm{ppx35/F}$ & CCATAACATCGGTGGACGGTGGACAGG & 434 & 27 & $59.26 / 59.26$ & $70.88 / 70.88$ \\
\hline & $\mathrm{PP} \times 35 / \mathrm{R}$ & ССАTTACATCCCGTCCССТCСССТTCA & & 27 & $59.26 / 59.26$ & $70.68 / 70.68$ \\
\hline \multirow[t]{2}{*}{10} & $\mathrm{PP} \times 39 / \mathrm{F}$ & CCGACGGAGTGTCCCTGGACCATCTTA & 229 & 27 & $59.26 / 59.26$ & $70.68 / 70.68$ \\
\hline & PP x39R & CCAGCGTTTTTGGTTCCCTTACCCCGTA & & 28 & $53.57 / 53.57$ & $69.01 / 69.01$ \\
\hline \multirow[t]{2}{*}{11} & $\mathrm{PP} \times 45 / \mathrm{F}$ & TGTTGGACATCACACCTACCGTGGA & 205 & 25 & $52 / 52$ & $66.22 / 66.22$ \\
\hline & $\mathrm{PP} \times 45 / \mathrm{R}$ & TCCGTACCTGACCCAGAAGATGCAA & & 25 & $52 / 52$ & $66.22 / 66.22$ \\
\hline \multirow[t]{2}{*}{12} & $\mathrm{pp} \times 51 / \mathrm{F}$ & CAACTAGCAACGGCGATGGACTG & 299 & 23 & $56.52 / 56.52$ & $66.33 / 66.33$ \\
\hline & $\mathrm{pp} \times 51 / \mathrm{R}$ & CTGCTTCGCGGGCTGACTAGAA & & 22 & $59.09 / 59.09$ & $66.4 / 66.4$ \\
\hline \multirow[t]{2}{*}{13} & $\mathrm{pp} \times 52 / \mathrm{F}$ & GGTGTTGGTGCTGGTGCTTTTGCTA & 517 & 25 & $52 / 52$ & $66.22 / 66.22$ \\
\hline & $\mathrm{PP} \times 52 / \mathrm{R}$ & CAGTTACAGGGGGACGAATGGTGGA & & 25 & $56 / 56$ & $67.87 / 67.87$ \\
\hline \multirow[t]{2}{*}{14} & $\mathrm{pp} \times 56 / \mathrm{F}$ & TGTTGTTTTTCCGCCATTTTGTACATGCAACC & 330 & 32 & $40.63 / 40.63$ & $65.93 / 65.93$ \\
\hline & $\mathrm{PP} \times 56 / \mathrm{R}$ & TGGCCTACATAGTGTATTCTGCAAGCCAAAAC & & 32 & $43.75 / 43.75$ & $67.21 / 67.21$ \\
\hline \multirow[t]{2}{*}{15} & $\mathrm{pp} \times 58 / \mathrm{F}$ & ACCACCGAGGCCACCAACAACGAAAGT & 128 & 27 & $55.56 / 55.56$ & $67.21 / 67.21$ \\
\hline & $\mathrm{PP} \times 58 / \mathrm{R}$ & CGTGGTCTACTGTCCACGGCGCAGTCT & & 27 & $62.96 / 62.96$ & $72.2 / 72.2$ \\
\hline \multirow[t]{2}{*}{16} & $\mathrm{PP} \times 59 / \mathrm{F}$ & CCGAGCAAGACACCTAAGACAGCAACG & 169 & 27 & $55.56 / 55.56$ & $69.16 / 69.16$ \\
\hline & $\mathrm{PP} \times 59 / \mathrm{R}$ & TCGGAGTCGGAGTCAGGTAATTGCT & & 25 & $52 / 52$ & $66.22 / 66.22$ \\
\hline \multirow[t]{2}{*}{17} & $\mathrm{PP} \times 66 / \mathrm{F}$ & GCGGGCGGCTCCTACСTCTTCСТCTTC & 277 & 27 & $66.67 / 66.67$ & $73.71 / 73.71$ \\
\hline & $\mathrm{PP} \times 66 / \mathrm{R}$ & CCACCTAACCTGACACACACTGCCCAAGG & & 29 & $58.62 / / 58.62$ & $71.69 / 71.69$ \\
\hline
\end{tabular}

Note: Primary Source: NCBI gene bank. (http//www.ncbi.nih.gov/genbank). Inqaba biotechnical industries (pty) Hartfield, South Africa. GC\%= guanine-cytosine percentage expressed as minimum and maximum, $\mathrm{Tm}=$ melting temperature. $\mathrm{R}=$ reverse primer, $\mathrm{F}=$ forward primer.

Table 2: Relationship between interleukins expression and cervical HPV infection among participants studied.

\begin{tabular}{|c|c|c|c|c|c|}
\hline parameters & Hpv & Hpv & t- test & df & p. value \\
\hline & negative (n=11) & positive $\mathrm{n}=(39)$ & & 48 & $<0.0001^{* * *}$ \\
\hline IL-4 & $3.0 \pm 0.067$ & $3.9 \pm 0.120$ & 6.6 & 48 & $<0.0001^{* * *}$ \\
\hline IL-6 & $4.8 \pm 0.061$ & $14.0 \pm 0.037$ & 78 & 48 & $<0.0001^{* * *}$ \\
\hline IL-8 & $13.0 \pm 0.027$ & $36.0 \pm 0.035$ & 420 & 48 & $<0.0001^{* * *}$ \\
\hline 1L-10 & $2.5 \pm 0.058$ & $16.0 \pm 0.100$ & 110 & 48 & $<0.0001^{* * *}$ \\
\hline IL-12 & $25.0 \pm 0.054$ & $37.0 \pm 0.046$ & 110 & & 48 \\
\hline
\end{tabular}




\begin{tabular}{|c|c|c|c|c|c|}
\hline IL-17 & $7.7 \pm 0.034$ & $8.6 \pm 0.068$ & 12 & 48 & $<0.0001^{* * *}$ \\
\hline IL-18 & $33.0 \pm 0.044$ & $36.0 \pm 0.035$ & 35 & 48 & $<0.0001^{* * *}$ \\
\hline IFN $-y$ & $0.98 \pm 0.043$ & $0.46 \pm 0.005$ & 59 & 48 & $<0.0001^{* * *}$ \\
\hline TNF & $26.0 \pm 0.026$ & $11.0 \pm 0.046$ & 29 & $<0.0001^{* * *}$ \\
\hline
\end{tabular}

Note: $\mathrm{IL}=$ interleukins, IFN- $\gamma=$ interferon gamma, TNF= Tumour necrotic factor, HPV =cervical human papillomavirus, value expressed as Mean \pm SD in $\mathrm{pg} / \mathrm{ml},{ }^{* *}$ statistically significant differences observed, $\mathrm{p}<0.01$.

\section{Discussion}

Pro-inflammatory and anti-inflammatory cytokines expressions were observed in this present study. This present study observed a statistically significant increase in the various interleukins studied, IL-4, IL-6, IL-8, IL-10, IL-11, IL-18, and TNF while IFN and IL-12 showed a statistically significant increase expression among HPV positive subjects compared with HPV negative participants. Previous reports have shown a relationship between interleukins and some disease conditions and therefore the need to evaluate their presence or absence in cervical HPV. Increased circulating IL-4 and IL-10 as observed in the current study among HPV positive women is in concordance with previous works [17-19]. Shekari, et al. [20] had linked IL-4 (Rp1/Rp2) gene polymorphism to double the risk of cervical cancer in which case HPV was a major risk factor in their study. Furthermore, Serum IL -10 was statistically significant in women with HPV infection compared with negative subjects in our present study and is in agreement with Feng, et al. [21] who reported that increase in serum levels of IL-10 was observed in women with advanced cervical cancer and high-grade cervical intraepithelial neoplasia. Local levels of IL-10 in cervicovaginal secretions were observed to have increased in women with HIV and HPV associated with cervical intraepithelial neoplasia(CIN) [22-24] as well as IL-10 polymorphism have been reported and correlated with some immunological disorders and cervical cancer $[20,25]$. Elevated serum levels of serum IL-6 was reported in the current study among women with cervical HPV infection compared with HPV negative participants. Several authors have reported high circulating IL-6 in both pathological and physiological conditions [26]. Also, Bustamam, et al. [27] had reported IL-6 relationship with cervical carcinogenesis and cervical intraepithelial neoplasia (CIN) which preceded to cervical cancer in an animal model. He reported a significant correlation between local cervico-uterine and serum levels of IL-6 with increasing grades of CIN and metastasis. High levels of IL-6 have been observed in cervico-vaginal washings and in serum of individuals with intraepithelial neoplasia and cancer of the cervix in accordance with Tavares-Murta, et al. and Tjiong, et al. [28,29]. Similarly, serum circulating IL-8 level shows increased mean concentration in women with HPV infection in our present study. High levels of IL-8 have been reported in previous works related to lung, colorectal, breast, brain, liver, bone and gynecological cancers [30-32]. Also, Wu, et al. [2] documented that patients with cervical cancer whose cervical biopsy expresses IL-8 were likely to have lymph node metastasis. Baker, et al. [33] also documented increased plasma levels of circulating IL-8 in elderly women with persistent HPV infection. Interleukin-12 (IL-12) appears to be immuno-protective in cervical HPV in the present study. The present study reported a statistically significant reduction in the level of IL-12 expression in HPV positive participants compared with negative participants. Yang, et al. [18] reported that reduced expression of IL-12 in cervical biopsy specimens from invasive cancer cases. Souza, et al. [34] also reported higher serum level of IL-17 expression in LSIL patients as seen in the present study. Liu, et al. [35] has established an association between Tumor Necrotic Factor (TNF) polymorphism with increased risk of cervical cancer. Interestingly TNF-a gene polymorphism can increase or decrease the susceptibility to cervical cancer depending on whether it is TNF-a- allele or TNF-a- is altered [36] wealso observeda decreased circulation of TNF among HPV positive participant. Parmar and Plantains, [37] has reported on the immunoprotective nature of interferon and that they can be defective and deficient in cervical cancer. The present study observed a defective interferon among HPV positive women as seen in (Table 3). According to Boccardo, et al. [38] interferon has been evaluated in experimental and clinical studies for immune function capabilities. IFN therapy has been used in patients with cervical intraepithelial neoplasia to cure or arrest of the cervical lesion progression [38,39]. HPV interfere with the protective action of IFNs at several levels and allow escape of HPV virus from immune degradation or clearance [3, 35, 40]. Gillet, et al. [41] optioned that Bacterial Vaginosis (BV) is characterized by a depletion of Lactobacillus species and a concurrent overgrowth of anaerobic bacteria and the presence of potentially pathogenic bacteria which are most frequently detected in the vaginal tract. In our present study the prevalence of bacterial vaginosis among HPV positive, HPV negative and high-risk HPV were $35.9 \%$ and $18.2 \%$ and $51.7 \%$ as shown in Table 4 and Table 5 respectively and agrees with previous works. Pamela, et al. [42] has reported a $31.5 \%$ prevalence of bacterial vaginosis among indigenous Paraguayan and is in accordance with our finding in HPV infection. Also, previous studies have reported $47.2 \%, 43.7 \%$ and $15.2 \%$ respectively [43-45] respectively. Furthermore, the present study recorded a statistically significant relationship between high risk HPV and BV ( $\mathrm{P}<0.02$; OR =9.46; 95\% CI, 1.08-86.26) and lack of statistically significant relationship between HPV in general and $\mathrm{BV}(\mathrm{P}<0.46 ; \mathrm{OR}=2.5 ; 95 \% \mathrm{CI}=, 0.47-13.4)$. Gillet, et al. [41] performed a meta-analysis, in which twelve eligible studies were selected to review the association between BV and HPV infection and a strong relationship was established [41]. Also, in the work of Nardis, et al. [46] the overall estimated odds ratio showed a positive association 
between BV and cervical HPV infection $(\mathrm{OR}=1.43$; 95\% $\mathrm{CI}=1.11$ 1.84). This magnitude of association between Bacterial Vaginosis (BV) and HPV infection has varied in epidemiological studies and Table 3: Association between bacterial vaginosis and HPV DNA. still remains controversial, yielding a whole lot of conflicting results and ranging from absence of any association [45] to a clear positive relationship [41] in accordance with our findings.

\begin{tabular}{|c|c|c|c|c|c|}
\hline Nugent score & HPV+ & HPV- & OR & p value & 0.3 \\
\hline $0-3(\mathrm{~N})$ & $20(51.3)$ & $08(72.7)$ & 0.39 & 1 & $0.09-1.7$ \\
\hline $4-6(\mathrm{IN})$ & $04(10.3)$ & $01(9.0)$ & 1.14 & 0.46 & $0.47-11.4$ \\
\hline $7-10(\mathrm{BV})$ & $14(35.9)$ & $02(18.2)$ & 2.5 & & \\
\hline Total & $39(100)$ & $11(100)$ & & \\
\hline
\end{tabular}

$\mathrm{N}=$ Normal smear, $\mathrm{IN}=$ Intermediate smear, $\mathrm{BV}=$ Bacterial Vaginosis, HPV $+=$ Human Papillomavirus positive, $\mathrm{HPV}-=\mathrm{Human}$ Papillomavirus negative, OR = Odds Ratio, 95\% CI = 95\% Confidence Interval

Table 4: Association between Bacterial Vaginosis and High-Risk HPV.

\begin{tabular}{|c|c|c|c|c|c|}
\hline Nugent score & HR-HPV+ & HPV- & OR & p value & 0.14 \\
\hline $0-3(\mathrm{~N})$ & $8(33.3)$ & $8(72.7)$ & 0.26 & 0.58 & $0.05-1.2$ \\
\hline $4-6(\mathrm{IN})$ & $03(12.5)$ & $01(9.0)$ & 0.46 & $0.02 *$ & $1.08-86.26$ \\
\hline $7-10(\mathrm{BV})$ & $13(54.7)$ & $02(18.2)$ & 9.64 & & \\
\hline Total & $24(100)$ & $11(100)$ & & \\
\hline
\end{tabular}

$\mathrm{N}=$ Normal smears, IN = Intermediate smear, BV = Bacterial Vaginosis, HR-HPV+ = high risk human Papillomavirus positive, $\mathrm{HPV}$ = Human Papillomavirus negative, OR = Odds Ratio, 95\% CI = 95\% Confidence Interval, * Significant association observed between Bacterial Vaginosis and High Risk HPV, $\mathrm{p}<0.05$.

Table 5: Full blood count of participants studied.

\begin{tabular}{|c|c|c|c|c|c|}
\hline Haematological parameters & HPV positive & HPV negative & $\mathrm{X} 2$ & p.value & 0.05 \\
\hline Red Blood Cell count $(103 / \mathrm{mm})$ & $4.4 \pm 0.5$ & $4.5 \pm 0.5$ & 0.4 & 0.5 & ns \\
\hline White Blood count $(106 / \mathrm{mm})$ & $6.5 \pm 1.2$ & $5.5 \pm 1.6$ & 2.6 & 0.1 & ns \\
\hline Platelets count & $259.3 \pm 57$ & $227.8 \pm 57$ & 6.8 & 0.001 & $* * *$ \\
\hline Mean Cell Haemoglobin (pg) & $27.3 \pm 2.5$ & $27.2 \pm 2.6$ & 1 & 0.74 & ns \\
\hline Mean Cell Volume & $84.7 \pm 6.2$ & $86.8 \pm 6.6$ & 1.1 & 0.3 & ns \\
\hline MeanCell Haemoglobin Con.(\%) & $32.2 \pm 1.2$ & $32.6 \pm 1.4$ & 0 & 0.87 & ns \\
\hline Haemoglobin (g/dl) & $12.87 \pm 1.5$ & $12.3 \pm 2.1$ & 0 & 0.88 & ns \\
\hline PCV (\%) & $39.5 \pm 4.3$ & $38.5 \pm 4.1$ & 0.4 & 0.49 & ns \\
\hline Neutrophils (\%) & $50.6 \pm 8.5$ & $45.2 \pm 8.3$ & 2.9 & 0.001 & $* * *$ \\
\hline Lymphocytes (\%) & $44.4 \pm 7.3$ & $45.0 \pm 8.3$ & 3 & 0.08 & ns \\
\hline Monocytes (\%) & $9.5 \pm 4.5$ & $6.3 \pm 2.6$ & 0.6 & 0.42 & ns \\
\hline
\end{tabular}

Full blood count evaluated in our current study showed a statistically significant reduction in platelets among HPV positive subjects as well as neutrophils (Table 5) Thrombocytopenia in response to viral infections is often multifactorial. Thrombocytopenia in viral hepatitis is caused by platelet specific glycoprotein antibodies [47] and immune complexes form bound to platelet surface to cause platelets destruction [48]. Coagulation, inflammation, and platelet activation play a role in HCV-induced decrease of platelet count. HCV also indirectly affects megakaryopoiesis [48,49]. The mechanism of platelets destruction in HPV might be linked to inflammatory response. In conclusion bacterial Vaginosis showed a strong relationship with high risk human Papillomavirus, indicating that a healthy vaginal flora will not only protect a woman from the acquisition of sexually transmitted viruses but also high-risk HPV. Interleukins participate in HPV infection and association interferon levels were depleted in HPV infected participants. Thrombocytes and neutrophils are cellular mediators in genital HPV infection. It is recommended therefore that women exposed to high-risk HPV should be screened for bacterial vaginosis, with concomitant estimations of levels of platelets as well as inflammatory cytokines.

Conflict of interest: There is no conflict of interest 


\section{References}

1. World Health Organization/ICO (2014) Information on HPV and Cervical Cancer (HPV Information Centre). Summary report on HPV and Cervical Cancer statistics in Nigeria.

2. Wu S, Shang H, Cui L (2013) Targeted blockade of interleukin-8 abrogates its promotion of cervical cancer growth and metastasis. Molecular Cell Biochemistry 375(1): 69-79.

3. Mission DR, Abdalla DR, Borges AM (2011) Cytokine serum levels in patients with cervical intraepithelial neoplasia grade II-III treated with intralesional interferon- $\alpha$ 2b. Tumorigenesis 97(5): 578-584.

4. Shukla S, Sisodia G, Mahata S, Headau S, Pandey A (2010) Aberrant expression and constitutive activation of STAT3 in cervical carcinogenesis: implications in high-risk human Papillomavirus infection. Molecular Cancer 9: 282-294.

5. Louache F, Bettaieb A, Henri A, Oksenhendler E, Farcet JP, et al. (1991) Infection of megakaryocytes by human immunodeficiency virus in seropositive patients with immune thrombocytopenic purpura Blood 78(7): 1697-1705.

6. Zapata JC, Cox D, Salvato MS (2014) The role of platelets in the pathogenesis of viral hemorrhagic fevers. PLoS Neg ITrop Dis 8(6): e2858.

7. Iannacone M, Sitia G, Isogawa M, Whitmire JK, Marchese P, et al. (2008) Platelets prevent IFN-alpha/beta-induced lethal hemorrhage promoting CTL- dependent clearance of lymphocytic choriomeningitis virus. Proc Nat lAcad Sci USA 105: 629-634.

8. Pozner RG, Ure AE, JaquenoddeGiusti C, D AtriL P, Italiano JE, et al. (2010) Junin virus infection of human hematopoietic progenitors impairs invitro proplatelet formation and platelet release via abystander effect involving type I IFN signaling. PLoS Pathog 6: e1000847.

9. Lutteke N, Raftery MJ, Lalwani P, Lee MH, Giese T, et al. (2010) Switch to high-level virus replication and HLA class I up regulation in differentiating megakaryocytic cells after infection with pathogenic hanta virus. Virology 405(1): 70-80.

10. Metcalf Pate KA, Lyons CE, Dorsey JL, Shirk EN, Queen SE, et al. (2013) Platelet activation and platelet monocytes aggregate formation contribute to decreased platelet count during acute simian immunodeficiency virus infection in pig tailed macaques. J InfectDis 208: 874-883.

11. Singh MV, Davidson DC, Kiebala M, Maggirwar SB (2012) Detection of circulating platelet-monocyte complexes in persons infected with human immunodeficiency virus type-1. J Virol Methods 181(2): 170176.

12. Nnodi J, Meledu SC, Dioka CE, Martin I, UKaibe N, et al. (2015) Cytokines expression in homozygous sickle cell Anaemia. Journal of Krishna institute of medical science university 4(1): 34-37.

13. Schapkaitz E, Levy B (2015) Critical limits for urgent clinician notification at South Africaintensive care. International journal of laboratory haematology 37: 5 .

14. Nugent RP, Krohn MA, Hillier SL (1991) Reliability of diagnosing bacterial vaginosis is improved by a standardized method of Gram stain interpretation. Journal of Clinical Microbiology 29(2): 297-301.

15. Mendoza L, Mongelos P, Malvina P, Amadin C, Isabel RR, et al. (2013) Human Papillomavirus and other genital infection in indigenous women from Paraguary: A cross sectional analytical study. BioMedical central Infectious disease 13: 531.

16. Nishiwaki M, Yamamoto T, Tone S (2008) Genotyping of human papillomaviruses by a novel one-step typing method with multiplex PCR and clinical applications. Journal of Clinical Microbiology 46(4): 11611168.

17. Olver S, Apte S, Baz A, Kienzle N (2007) The duplicitous effects of interleukin 4 on tumour immunity: how can the same cytokine improve or impair control of tumour growth? Tissue Antigens 69(4): 293-298.
18. Yang YC, Lee ZY, Wu CC (2007) CXCR4 expression is associated with pelvic lymph node metastasis in cervical adenocarcinoma. International Journal of Gynaecology and Cancer 17: 676-686.

19. Peghini BC, Abdalla DR, Barcelos AC (2012) Local cytokine profiles of patients with cervical intraepithelial and invasive neoplasia. Human Immunology 73(9): 920-926.

20. Shekari M, Kordi-Tamandani DM, MalekZadeh K (2012) Effect of antiinflammatory (IL-4, IL-10) cytokine genes in relation to risk of cervical carcinoma. American Journal of Clinical Oncology 35(6): 514 - 519.

21. Feng Q Wei H, Morihara J (2012) Th2 type inflammation promotes the gradual progression of HPV-infected cervical cells to cervical carcinoma. Gynaecology and Oncology 127(2): 412-419.

22. Mhatre M, McAndrew T, Carpenter C, Bur RD, Einestein MH, et al. (2012) Cervical intraepithelial neoplasia associated tract mucosa. Sexual Transmission Disease. 39(18): 591-597.

23. Asadullah K, Sterry W, Volk HD (2003) Interleukin-10 therapy-review of a new approach. Pharmacology Review 55: 241-269.

24. Bijjiga E, Martino AT (2013) Interleukin 10 (IL-10) regulatory cytokine and its clinical consequences. Journal of Clinical Cell Immunology 1: 007.

25. Moore MA, Ariyar Y, Badar F (2010) Cancer epidemiology in South Asiapast, present and future. Asian Pacific Journal of Cancer Preview 11: 4966.

26. Vici P, Mariani L, Pizzuti L (2014) Emerging biological treatments for uterine cervical carcinoma. Journal of Cancer 5(2): 86-97.

27. Bustamam A, Ibrahim N, Devi N (2008) The establishment and use of an in vivo animal model for cervical intra-epithelial neoplasia. International Journal of Cancer Research 4: 61-70.

28. Tavares-Murta BM, de Resende AD, Cunha FQ, Murta EF (2008) Local profile of cytokines and nitric oxide in patients with bacterial vaginosis and cervical intraepithelial neoplasia. European Journal of Obstetrics and Gynecology Reproductive Biology 138(1): 93-99.

29. Tjiong MY, van der Vange N, Kate FJ (1999) Increased IL-6 and IL-8 levels in cervicovaginal secretions of patients with cervical cancer. Gynecology and Oncology 73: 285-291

30. Murooka TT, Ward SE, Fish EN (2005) Chemokines and cancer Ch.2. In cytokines and cancer. Cancer Treatment and Research 126: 15-44.

31. Heikkila ES, Lawlor DA (2008) Systematic review of the association between circulating interleukin-6 (IL-6) and cancer. European Journal of Cancer 44: 937-945.

32. Zarogoulidis P, Yarmus L, Zarogoulidis K (2013) Interleukin-6 cytokine: A multifunctional glycoprotein for cancer. Immune Research 9(62): $16635-16680$

33. Baker R, Dauner JG, Rodriguez AC (2011) Increased plasma levels of adipocytes and inflammatory markers in older women with persistent HPV infection. Cytology 53: 282-285.

34. Souza JM, Matias BF, Rodrigues CM, Murta EF, Michelin MA (2013) IL-17 and IL-22 serum cytokine levels in patients with squamous intraepithelial lesion and invasive cervical carcinoma. European Journal of Gynaecology and Oncology 34: 466-468.

35. Liu L, Yang X, Chen X (2012) Association between TNF- $\alpha$ polymorphisms and cervicalcancer risk: A meta-analysis. Molecular Biology 39(3): 2683-2688.

36. Pan F, Tian J, Ji CS (2012) Association of TNF- $\alpha-308$ and -238 polymorphisms with risk of cervical cancer: a meta-analysis.Asian Pacific Journal of Cancer Preview 13: 5777-5783.

37. Parmar S, Platanias, LC (2007) Interferon's. Cytokines and Cancer 45: 68. 
38. Boccardo E, Lepique AP, Villa LL (2010) The role of inflammation in HPV carcinogenesis. Carcinogenesis 31: 1905-1912.

39. Machado FA, Janssens Jp, Michelin MA, Murta EF (2012) Immune response andimmunotherapy in intraepithelial and invasive lesions of the uterine cervix. Clinical and Experimental Obstetrics and Gynaecology 39: 27-31.

40. Tirone NR, Michelin MA, Murta EF (2010) Using cytokines to treat cervical intraepithelial and invasive neoplasia. Recent Patents on Anticancer Drug Discovery 5(2): 165-169.

41. Gillet E, Meys J, Verstraelen H (2011) Bacterial vaginosis is associated with uterine cervical human Papillomavirus infection: a meta-analysis. Biomedical central, Infectious Disease 11: 10.

42. Pammela M, Laura PM, Isabel R (2015) Distribution of human papillomavirus (HPV) genotypes and bacterial vaginosis presence in cervical samples from Paraguayan indigenous women. International journal of infectious disease 39: 44-49.

43. Samoff E, Koumans EH, Markowitz LE (2005) Association of Chlamydia trachomatis with persistence of high-risk types of human papillomavirus in a cohort of female adolescents. American Journal of Epidemiology 162(1): $668-767$.

\section{ISSN: 2574-1241}

DOI: $10.26717 /$ BJSTR.2020.26.004296

Yibala Ibor Oboma. Biomed J Sci \& Tech Res

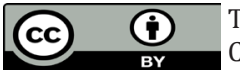

This work is licensed under Creative Commons Attribution 4.0 License

Submission Link: https://biomedres.us/submit-manuscript.php
44. Watts DH, Fazarri M, Minkoff H (2005) Effects of bacterial vaginosis and other genital infections on the natural history of human Papillomavirus infection in HIV-1-infected and high-risk HIV- 1-uninfected women. Journal of Infectious Disease 191(3): 1129-1139.

45. Rahkola P, Mikkola TS, Ylikorkala O (2009) Association between high risk Papillomavirus DNA and nitric oxide release in the human uterine cervix. Gynecology and Oncology 114: 323 - 326.

46. Nardis C, Mosca L, Mastromarino P (2013) Vaginal microbiota and viral sexually transmitted diseases. Annali di Igiene 25(5): 443-456.

47. Zhang W, Nardi MA, Borkowsky W, Li Z, Karpatkin S (2009) Role of molecular mimicry of hepatitis C virus protein with platelet GPIIIa inhepatitis C-related immunologic thrombocytopenia. Blood 113(17): 4086-4093.

48. Weksler BB (2007) Review article: The pathophysiology of thrombocytopenia in hepatitis $\mathrm{C}$ virus infection and chronic liver disease. Aliment Pharmacol Ther 26(Suppl1): 13-19.

49. Flaujac C, Boukour S, Cramer-Borde E (2010) Platelets and viruses: An ambivalent relationship. Cell MolLifeSci 67(4): 545-556.

$\begin{array}{ll}\text { BIOMEDICAL } & \text { Assets of Publishing with us } \\ \text { RESEARCHES } & \text { - Global archiving of articles } \\ \text { - Immediate, unrestricted online access }\end{array}$

